the School of Medicine, which had just been amalgamated with the Yorkshire College of Science in order to become a constituent of the Victoria University and had received a nucleus of an endowment of a chair in memory of Lord Frederick Cavendish. There was practically no equipment and as little money, so for ten years, while sharing in the work of a scheme for building a new school, he set about the task of equipping the department with the practical assistance of a young mechanical engineer-Kershawwho later made a name in the invention and manufacture of instruments for the film industry. When the new school was opened in 1893 it was extremely well equipped for practical courses, especially experimental physiology.

The necessities of the time seem to have diverted Birch's mind from inquiry into physiological problems, for which he had shown excellent promise in his work with Rutherford in Edinburgh. His attention was given to perfecting apparatus: unless perfect an instrument was no use; when perfect it ceased to have interest. His bent for organization and making the fullest use of slender funds was well shown in his military hobby. He raised a medical staff corps with such success that little improvement was required to make it a full unit in the Haldane scheme. He retired with the distinction of C.B. after serving as A.D.M.S. of the unit of his own creation. In 1915, although more than sixty years of age, he was invited to resume the rank, and he accompanied the division to France.

The same bent was marked in the organization and discipline of Birch's department and in his conduct of the affairs of the Faculty in the dean's chair, which he occupied in the first seven years of the century and again from 1913 until his retirement in 1917. In these periods he laid certain lines along which the post-War development of the school were facilitated. In these days of grants of a liberality entirely unknown in the Victorian period, this generation can scarcely understand the amount of labour and ingenuity exercised by men like Birch in laying the foundations of a department in the condition of magna inopia omnium rerum. Though unquoted in text-books, he is one of the corner stones of the Leeds Medical School.

\section{Dr. W. N. Bond}

IT is with much regret that we record the death of Dr. W. N. Bond, lecturer in physics in the University of Reading, which occurred on August 25, following an operation, while on holiday at Minehead.

Wilfrid Noēl Bond was born on December 27, 1897, and educated first at St. Albans School and afterwards at East London College and the Royal College of Science, whence he graduated with first-class honours in the University of London. After nearly two years' experience in industrial research in the engineering works of Messrs. Kent in Luton, he returned to academic research work, first under Prof. A. W. Porter at University College, London, and later at the Cavendish Laboratory, under Sir J. J. Thomson, where he took his Cambridge B.A. by research. $\mathrm{He}$ was appointed lecturer in physics in the University of Reading in January 1921, a position which he continued to occupy with distinction until his death.

A kind, patient and conscientious teacher, Bond was also keenly interested in research and published numerous original papers. Readers of NATURE may recall his recent investigations into the most probable values of the universal constants, made in connexion with the theories of Sir Arthur Eddington. Bond's experimental work was mainly (though by no means exclusively) concerned with the flow of fluids, and the allied subjects of viscosity and surface tension. An experimenter of exceptional skill and ingenuity, his methods were distinguished by their elegance and simplicity. His research work showed a steady development in power and maturity, and his most recent publications on "The Viscosity of Air" and on the "Measurement of Surface Tension by the Moving Sheet Method" (a continuation of which was passing through the press at the time of his death) reveal his work at its best. In addition to his original papers, Bond published three books, "Numerical Examples in Physics", "An Introduction to Fluid Motion", and "Probability and Random Errors", all of which received very favourable notices.

Modest, friendly and sincere, Bond will be greatly missed, not only by his students and colleagues to whom at all times he gave unsparingly and unselfishly of his best, but also by a much wider circle of acquaintances and friends. He is survived by his father, and leaves a widow and three children.

\section{We regret to announce the following deaths :}

Sir John Dewrance, G.B.E., president of the Institution of Mechanical Engineers in 1923, on October 7, aged seventy-nine years.

Dr. Paul Emerson, senior soil scientist of the Soil Conservation Service of the U.S. Department of Agriculture, an authority on soil bacteria, on September 20, aged fifty years.

Mr. W. B. Ferguson, K.C., known for his researches in photography, on October 7, aged eighty-five years.

Mr. W. S. Gosset, head of the scientific staff of Arthur Guinness, Son and Co., Dublin, known for his contributions to statistics and economics over the pseudonym "Student", on October 16, aged sixty-one years.

Prof. L. M. Hoskins, emeritus professor of applied mathemațies in Stanford University, on September 8, aged seventy-seven years.

Sir Ashley Mackintosh, emeritus professor of medicine in the University of Aberdeen, an authority on nervous diseases, on October 14, aged sixty-nine years.

Sir John Moore, president of the Royal Academy of Medicine in Ireland in 1918-21 and president of the Royal College of Physicians of Ireland in 18981900, author of "Meteorology: Practical and Applied", on October 13, aged ninety-one years.

Prof. F. Morley, emeritus professor of mathematics, in Johns Hopkins University, on October 17, aged seventy-seven years. 